\title{
Optic Nerve Cavernous Venous Malformation
}

Sophie Anglaret, MD, and Augustin Lecler, MD, PhD

Neurology ${ }^{\circledR}$ 2021;96:31-32. doi:10.1212/WNL.0000000000011092
Correspondence

Dr. Lecler

alecler@for.paris

Figure MRI of the Orbits
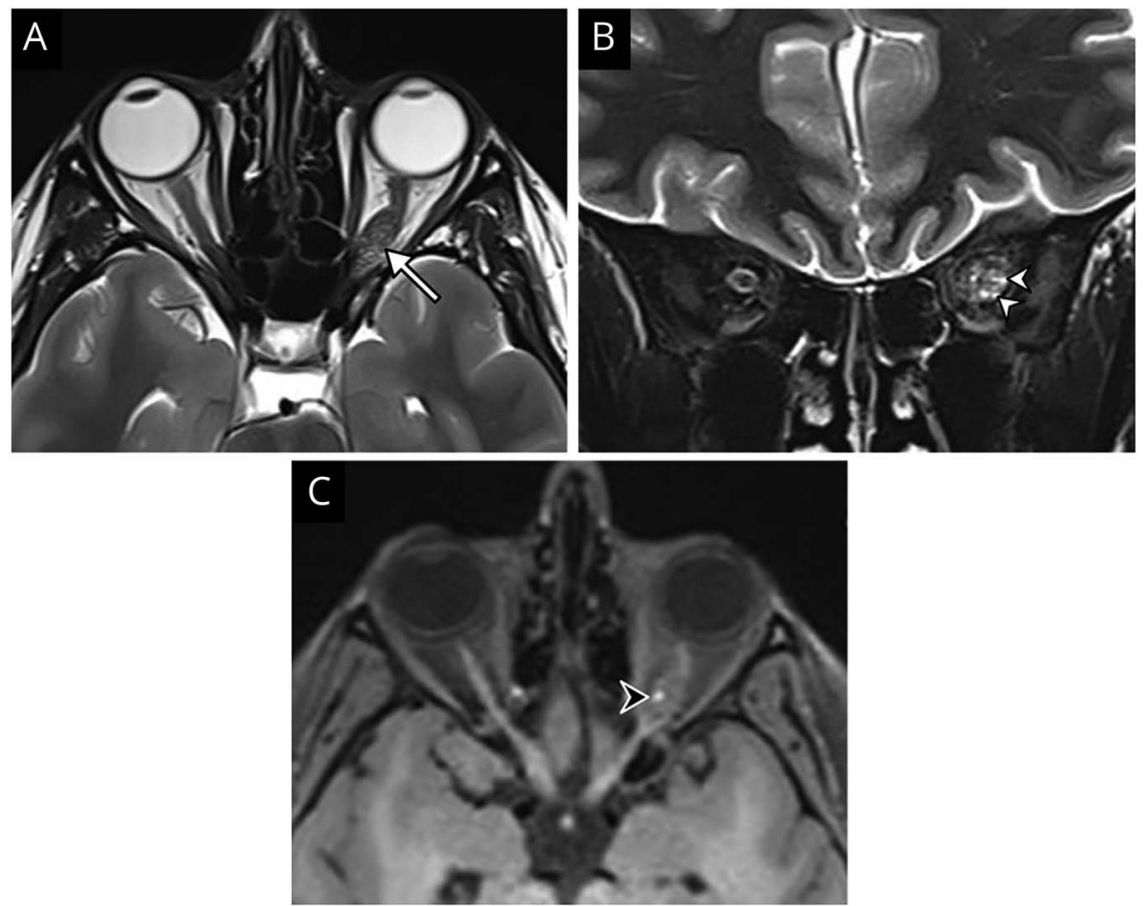

Axial (A) and coronal (B) T2-weighted MRI show an oval heterogeneous lesion of the posterior intraorbital part of the left optic nerve (arrow) with multiple high signal intensity loculi with liquid-liquid levels (white arrowheads) typical of cavernous venous malformation. Axial T1-weighted imaging (C) shows a hyperintense foci (black arrowhead), confirming recent bleeding.

A 28-year-old woman presented with rapidly progressing visual loss and left eye pain. Ophthalmologic examination, tonometry, and optical coherence tomography were normal, but static perimetry showed a left central scotoma. MRI revealed a left optic nerve lesion highly suggestive of cavernous venous malformation (CVM) (figure). Conservative treatment with oral corticosteroids was started. Pain decreased and visual acuity improved progressively to total recovery. Sequential follow-up MRI over 3 years showed no change in the lesion.

The optic nerve is a rare location of CVM. ${ }^{1}$ Surgical resection remains the standard treatment, but a less invasive approach might be preferred. ${ }^{1,2}$

\section{Study Funding}

No targeted funding reported.

\section{Disclosure}

The authors report no disclosures relevant to the manuscript. Go to Neurology.org/N for full disclosures.

From the Department of Neuroradiology, Adolphe de Rothschild Foundation Hospital, Paris, France.

Go to Neurology.org/N for full disclosures. 


\section{Appendix Authors}

\begin{tabular}{lll}
\hline Name & Location & Contribution \\
\hline $\begin{array}{l}\text { Sophie } \\
\text { Anglaret, } \\
\text { MD }\end{array}$ & $\begin{array}{l}\text { Fondation } \\
\text { Ophtalmologique A. de } \\
\text { Rothschild, Paris, France }\end{array}$ & $\begin{array}{l}\text { Collected images and drafted } \\
\text { the manuscript for intellectual } \\
\text { content }\end{array}$ \\
\hline $\begin{array}{l}\text { Augustin } \\
\text { Lecler, MD, } \\
\text { PhD }\end{array}$ & $\begin{array}{l}\text { Fondation } \\
\text { Ophtalmologique A. de } \\
\text { Rothschild, Paris, France }\end{array}$ & $\begin{array}{l}\text { Drafted the manuscript for } \\
\text { intellectual content }\end{array}$ \\
\hline
\end{tabular}

\section{References}

1. Liu JK, Lu Y, Raslan AM, Gultekin SH, Delashaw JB. Cavernous malformations of the optic pathway and hypothalamus: analysis of 65 cases in the literature. Neurosurg Focus 2010;29:E17.

2. Algoet M, Van Dyck-Lippens PJ, Casselman J, et al. Intracanal optic nerve cavernous hemangioma: a case report and review of the literature. World Neurosurg 2019;126: 428-433.

\section{NEW EPISODE}

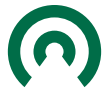

$\underset{\text { Poocast }}{\text { Neurology }}$

January 5, 2021

\section{Disease Activity in Pregnancy and Postpartum in Women with MS Who Suspended Rituximab and Natalizumab (see the November issue of Neurology Neuroimmunology \& Neuroinflammation)}

In the first segment, Dr. Stacey Clardy talks to National Academy of Medicine inductee Dr. Merit Cudkowicz about her research and work. In the second part of the podcast, Dr. Clardy talks with Dr. Katharina Fink about antibody therapy for pregnant women with multiple sclerosis.

Disclosures can be found at Neurology.org.

No CME this week: Interviews based on articles from Neurology ${ }^{\circledR}$ Clinical Practice, Neurology ${ }^{\circledR}$ Genetics, and Neurology: Neuroimmunology \& Neuroinflammation are excluded from the CME program.

\section{Missed the Fall Conference? It's Now Available On Demand!}

Even if you missed the 2020 AAN Fall Conference, you can still access the quality CME, expert faculty, and innovative science at your convenience with Fall Conference On Demand! Access now at AAN.com/20FC. 


\title{
Neurology
}

\author{
Optic Nerve Cavernous Venous Malformation \\ Sophie Anglaret and Augustin Lecler \\ Neurology 2021;96;31-32 Published Online before print October 22, 2020 \\ DOI 10.1212/WNL.0000000000011092
}

This information is current as of October 22, 2020

$\begin{array}{ll}\begin{array}{l}\text { Updated Information \& } \\ \text { Services }\end{array} & \begin{array}{l}\text { including high resolution figures, can be found at: } \\ \text { http://n.neurology.org/content/96/1/31.full }\end{array} \\ \text { References } & \text { This article cites } 2 \text { articles, } 0 \text { of which you can access for free at: } \\ & \text { http://n.neurology.org/content/96/1/31.full\#ref-list-1 } \\ & \text { This article, along with others on similar topics, appears in the } \\ & \text { following collection(s): } \\ \text { MRI } & \text { http://n.neurology.org/cgi/collection/mri } \\ & \text { Optic nerve } \\ \text { http://n.neurology.org/cgi/collection/optic_nerve } & \text { Orbit } \\ & \text { http://n.neurology.org/cgi/collection/orbit } \\ & \text { Visual loss } \\ \text { http://n.neurology.org/cgi/collection/visual_loss } & \\ & \text { Information about reproducing this article in parts (figures,tables) or in } \\ & \text { its entirety can be found online at: } \\ \text { http://www.neurology.org/about/about_the_journal\#permissions } \\ \text { Permissions \& Licensing } & \text { Information about ordering reprints can be found online: } \\ & \text { http://n.neurology.org/subscribers/advertise }\end{array}$

Neurology ${ }^{\circledR}$ is the official journal of the American Academy of Neurology. Published continuously since 1951, it is now a weekly with 48 issues per year. Copyright @ 2020 American Academy of Neurology. All rights reserved. Print ISSN: 0028-3878. Online ISSN: 1526-632X.

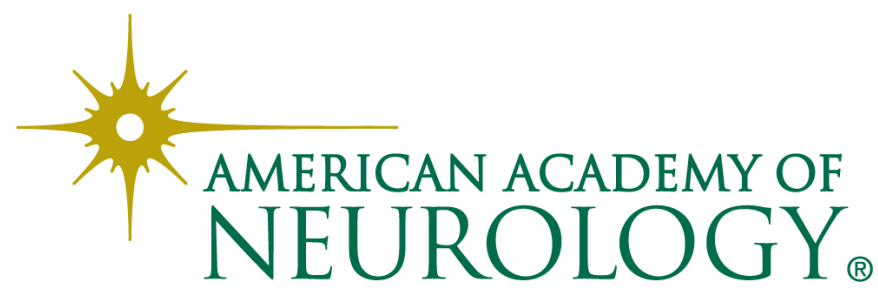

